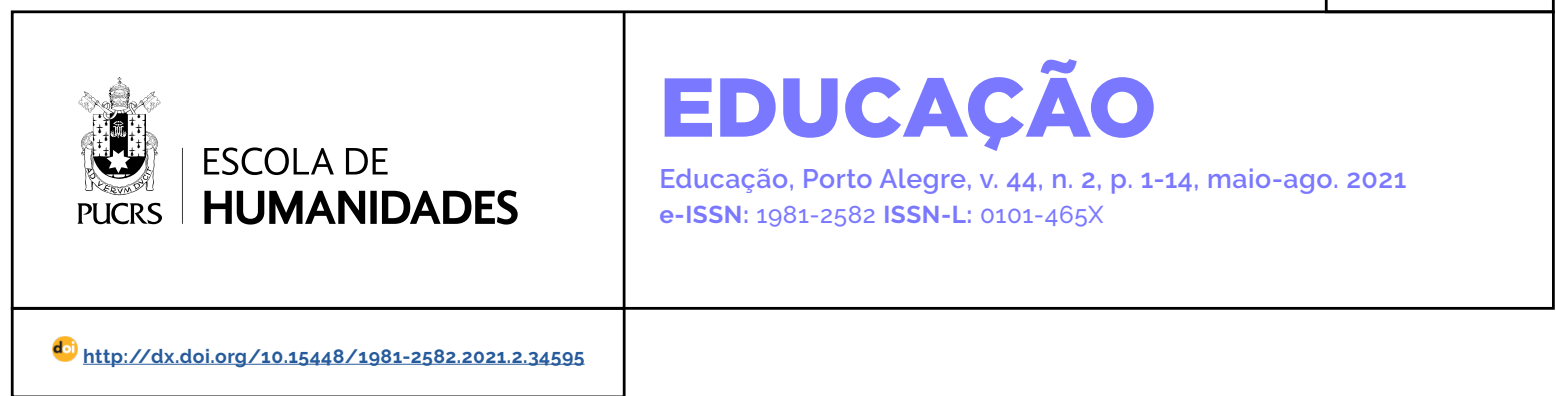

SEÇÃO: OUTROS TEMAS

\title{
Researches About Higher Education In Brazil
}

\author{
Estudos sobre educação no Ensino Superior no Brasil \\ Estudios en Educación Superior en Brasil
}

\author{
Asaph Armando \\ Jacinto ${ }^{1}$ \\ orcid.org/0000-0002-0543-4188 \\ asaph.jacinto@gmail.com
}

Recebido em: Jun. 25, 2019.

Aprovado em: Jun. 22, 2021.

Publicado em: Sep. 16, 2021
Abstract: The field of Higher Education is advancing worldwide. This work aimed to apply a bibliometric approach on scientific publications about education in the sector of Higher Education, especially concerning the Brazilian ones. For this purpose, the database of Web of Science was used. The analyzed indicators included the Brazilian position worldwide concerning the number of papers and of citations, languages of publications and international collaborations. They were compared with other countries in MERCOSUR and in Latin America. In addition, the main institutions and funding agencies in Brazil were verified. The results showed that Brazil is the most prolific country in the Latin America, and it is among the most important in the world too. Most of the Brazilian articles were in Portuguese Most of the Brazilian researchers were from public universities (e.g., USP, UFSC and Unesp) and supported by public agencies (as CNPq, CAPES and FAPESP). While most of the international collaborations happened with Portugal, Spain and USA. Besides that, suggestions of future studies in this area were indicated. Keywords: education, higher education, university, bibliometrics, scientometrics.

Resumo: O Ensino Superior está crescendo mundialmente e no Brasil. Este trabalho teve como objetivo realizar uma análise bibliométrica dos artigos científicos brasileiros sobre educação no ensino superior. Para isso, foi utilizada a base de dados do Web of Science. Foram verificados diversos indicadores, como a posição do Brasil mundialmente em relação ao número de publicações e de citações, idioma das publicações e colaborações internacionais. Esses dados foram comparados aos de outros paises no MERCOSUL e na América Latina. Além disso, as principais instituições e agências de fomento no país foram identificadas. Os resultados mostraram que o Brasil é o principal pais na América Latina nessa área e, também, está entre os maiores do mundo. A maior parte das publicações verificadas é em português, feita por universidades públicas (como USP, UFSC e Unesp), patrocinadas por agentes públicos (como CNPq. CAPES e FAPESP). Os maiores parceiros internacionais foram Portugal, Espanha e Estados Unidos. Além disso, foram indicadas sugestões de trabalhos futuros.

Palavras-chave: educação; ensino superior, universidade, bibliometria, cientometria.

Resumen: La educación superior está creciendo en todo el mundo. El objetivo de este trabajo fue realizar un análisis bibliométrico de artículos científicos brasileños sobre educación superior. Por lo tanto, se utilizó la base de datos Web of Science. Se verificaron indicadores como la posición de Brasil a nivel mundial en relación al número de publicaciones y citas, el idioma de las publicaciones y las colaboraciones internacionales. Estos datos se compararon con los de otros paises del MERCOSUR y América Latina. Además, se identificaron las principales instituciones y agencias de desarrollo del pais en esta área. Los resultados mostraron que Brasil es el principal pais de América Latina tanto en publicaciones como en citas, y también se encuentra entre los más grandes del mundo. La mayoría de publicaciones brasileñas fueran en portugués, realizadas por universidades públicas (como USP, UFSC y UFRGS), patrocinadas por agentes públicos 
(como CAPES, CNPq y FAPESP). Las colaboraciones internacionales más frecuentes fueron con Portugal, España y EE.UU. Además, se indicaron sugerencias para trabajos futuros.

Palabras clave: educación, educación superior, universidad, bibliometría, cienciometria.

\section{Introduction}

The access to the Higher Education is growing worldwide. Marginson (2016) stated that one-third of world population in the proper school age has already been enrolled in an institution of Higher Education. This is a reality in many countries, such as Brazil. National Institute for Educational Studies and Research "Anisio Teixeira" (Inep) is an agency of the Federal Government of Brazil. Every year, Inep publishes the Higher Education Census. This census collects data from Higher Education institutions in the country and profiles of courses, students and professors as well. In 2007, there were 2,281 institutions of Higher Education in Brazil, with over 5 million of students and 317 thousand professors (Inep, 2009). On the other hand, in 2019 there were 2,608 institutions in Brazil, with over 8.6 million students and almost 400 thousand professors (Inep, 2020). It is also interesting to mention that Brazil entered in the list with world class universities, e.g. with United States of America (USA), England and China (Waltman et al., 2012; Jöns \& Hoyler, 2013).

However, these advancements raise questions about the quality of this education in Brazil and in the world (Dias et al., 2006; Durham, 2018; Jöns \& Hoyler, 2013; Smeyers \& Burbules, 2011). In this context, the researches about the Higher Education are essential. They secure the innovations in this field. Otherwise, universities would always be restricted to the traditional transmitting of knowledge, without a contextualization neither an active participation of the learner (Biggs, 1996; Lindblom-Ylänne et al., 2006).

Diem and Wolter (2013) carried out a statistical analysis of scientific papers about education in Switzerland. In addition, Adams (2009) studied a group of bibliometric indicators about the quality of British institutions. Few papers tried to apply a similar approach concerning Brazil. One of them focused on the indicators of a specific course (Nursing) (Winters et al., 2018) while another considered the production of professors from the public institutions of only one Brazilian State (Goiás) (Maricato et al., 2016). Recently, Faria et al. (2018) carried out a study to determine the market value of Brazilian universities, but they used the database of a national university ranking (Ranking Universitário Folha - RUF) instead of direct data from scientific publications and databases. In this manner, this research aimed to apply a bibliometric procedure on scientific articles about education in the general sector of the Higher Education. So, it was possible to evaluate the Brazilian relevance in this area. It was compared with countries in MERCOSUR and in Latin America as well as worldwide. This study also checked the main Brazilian institutions and funding agencies. These results are valuable for public policies in Brazil and in other countries in MERCOSUR, with a similar educational context.

\section{Method}

Scientific papers about education in the sector of Higher Education were searched. Web of Science (WoS) database was chosen because it is one of the most reliable databases for bibliometric studies (Diem \& Wolter, 2013; Zhu \& Liu, 2020), especially for those written in Spanish and Portuguese (Vera-Baceta, Thelwall \& Kousha, 2019). The data were collected on 01 June 2021, considering publications from 1945 until 2020. The used Boolean expression was adapted from Heradio et al. (2016):

TS=(("higher educat") AND (teach* OR pedagog*))

Using the filter of Countries available on WoS, I could analyze the number of publications and citations for each country. Beyond that, in order to compare the Brazilian indicators in this sector with the national production other search expression was applied. It was $\mathrm{CU}=(\mathrm{x})$. This " $\mathrm{x}$ " was the country name (Brazil), but others were also verified as USA, Spain or Portugal. 
Further, the annual growth rate $\left(G_{i}\right)$ was determined to Brazil from each year $i$ (2010 to 2020), Eq. 1 (Milanez et al., 2013). These rates were also determined to the most cited countries in Latin America and in the world.

$$
G_{i}=\frac{100\left(N_{i}-N_{i-1}\right)}{N_{i-1}}(1)
$$

In the Eq. 1, $N_{i}$ and $N_{i-1}$ are the number of publications of the years $i$ and $i-1$, respectively. Then, the average growth rate (AGR) of publications was calculated as the simple average of all $G_{i}$

The main keywords of these papers were analyzed as well as if the journals with more Brazilian papers had active profiles in social media (Twitter and Facebook). At last, the main Brazilian institutions with more articles and the most mentioned funding agencies in this area were pointed out.

\section{Brazilian relevance and production}

The used Boolean expression on WoS recorded 36,066 results worldwide, with 221,680 citations. Figure 1 shows the countries with more papers and citations in the world (Figure $1 \mathrm{a}$ and Figure 1b, respectively) and in Latin America (Figure $1 \mathrm{c}$ and Figure $1 \mathrm{~d}$, respectively).

Figure 1 - Scientific papers about education in the Higher Education sector on WoS.
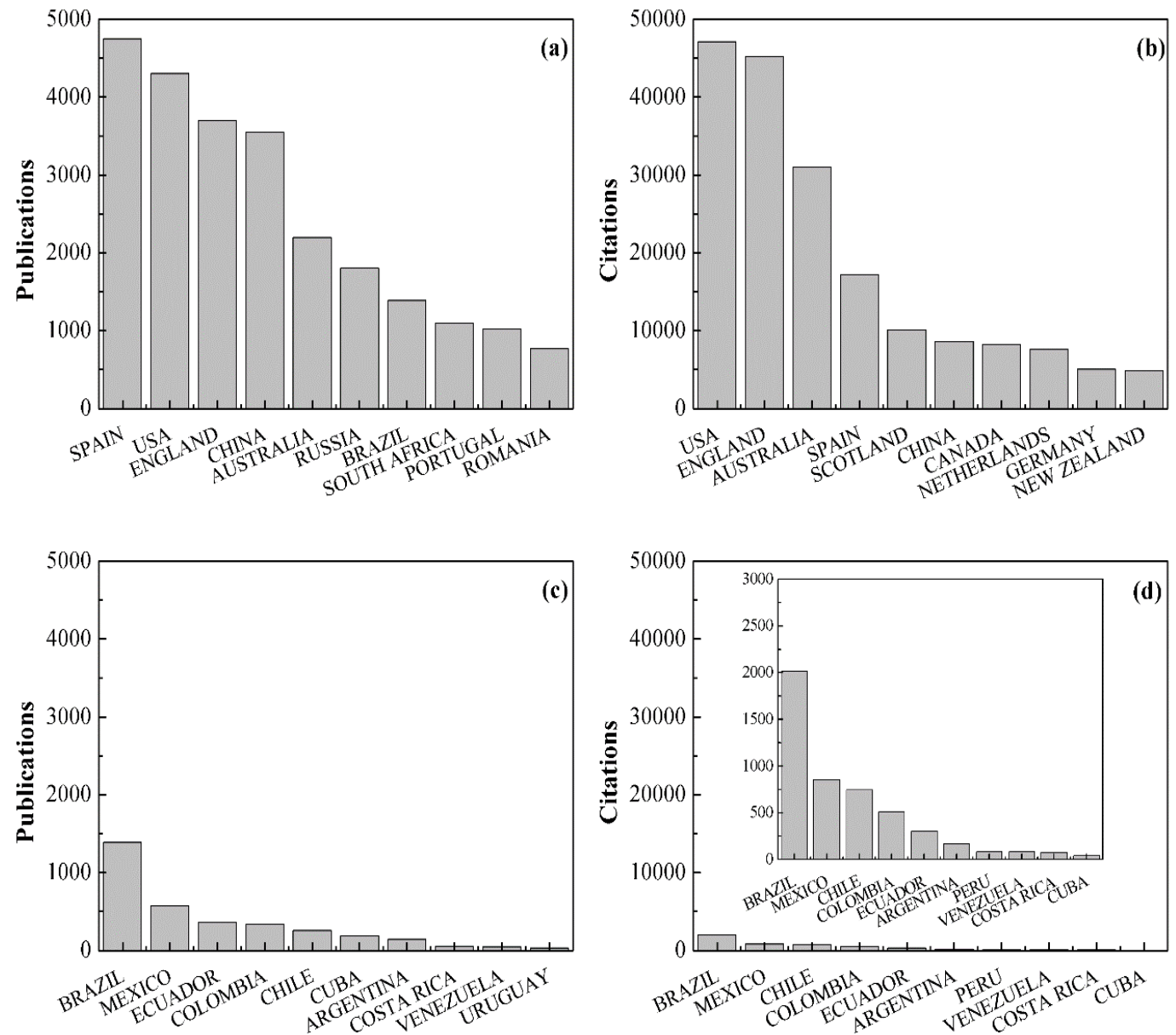

(a) countries with more articles worldwide; (b) countries with more citations worldwide; (c) countries with more articles in Latin America; (d) countries with more citations in Latin America.

Source: Prepared by the author based on research data. 
The results in Figure 1a indicate that this theme is of interest of distinct regions in the world. Nations from almost all regions were in the Figure 1a. They were European (Spain, England, Russia, Romania and Portugal), Asian (China), American (USA and Brazil), from Oceania (Australia) and even from Africa (South Africa). Only the Middle East did not have a member in the ranking of the Figure 1 a. The scene was similar concerning the citations (Figure 1b). Most cited authors in this area usually were European (from England, Spain, Scotland, Netherlands and Germany), American (USA and Canada), Asian (China) or from Oceania (Australia and New Zealand).

It is interesting to highlight the Brazilian production, occupying the $7^{\text {th }}$ position in the world (Figure 1a). Notwithstanding, it was the $24^{\text {th }}$ in citations. When we look at the Latin America, the relevance of Brazil is clear for it is the country with more papers (Figure 1c) and more citations (Figure 1d). Latin America published 3.347 articles, cited 4741 times. Brazilian researchers were responsible for 41.6 and $42.5 \%$ of publications and citations in Latin America, respectively.

Moreover, the analysis of Figure 1 suggests that amount of scientific production not always corresponds to an acknowledgment by its scientific community, regarding to the times cited. For instance, Hong Kong was the $99^{\text {th }}$ country in the world publication ranking, but the $27^{\text {th }}$ in citations. Another case was Russia, which was the $6^{\text {th }}$ with more papers, but the $23^{\text {nd }}$ in citations.

In addition, the citations report available on WoS shows many indicators for any searched dataset, such as total number of citations and papers without self-citations by their authors. It is better to avoid analyzing citations alone for an increasing of publications of one author or group could create "more 'targets' to be cited", as Adams (2009) stated. Brazilian papers were cited 2013 times, and 1851 of these times had no self-citations. With these numbers, it is possible to calculate that Brazil demonstrated a self-citation index of $8.0 \%$. This value is high if compared to other countries. For example, among the most cited nations worldwide (Figure 1b), only Spain showed a higher indicator than Brazil (13.9\%). All others were lower, as England (6.4\%), USA (3.9\%), Australia (5.6\%) or Scotland (1.5\%). The countries with the highest self-citations index were Honduras (36.4\%), Russia (17.8\%) and Angola (15.4\%). A further bibliometric study can concentrate itself in these papers with self-citations and evaluate their content and publication ethics.

As mentioned earlier, the search was carried between 1945 and 2020. The oldest paper on WoS was from 1956 (Wilson, 1956). The annual growth of the number of articles during 2001 to 2020 in the world is in Figure za while in the Brazil is in Figure $2 \mathrm{~b}$.

Figure 2 - Annual growth of scientific papers about education in the Higher Education sector on WoS from 2001 to 2018.
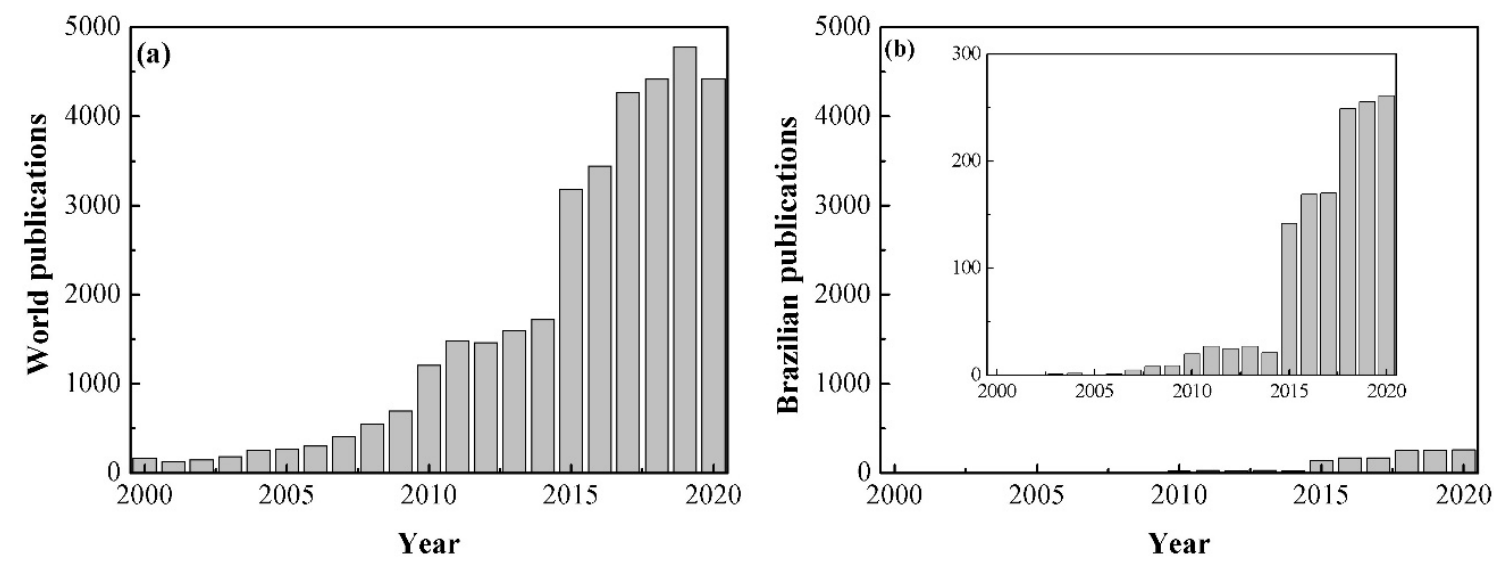

(a) worldwide; (b) in Brazil.

Source: Prepared by the author based on research data. 
A significant increasing in the amount of papers happened in 2015 in the world (Figure 2a) and in Brazil as well (Figure 2b). However, 2020 showed a lower value than 2019 worldwide (Figure 2a). This decreasing happened to almost all countries in Figure 1a, except Brazil, USA, Australia and South Africa. The average growth rate (AGR) in the world during the current decade (2011 to 2020) was 16.0\%.

On the other hand, the first paper on WoS of Brazilian authors in this field was published in 1993 (Klein \& Schwartzman, 1993). Since then, the researches about this area have been increasing. The results in Figure $2 \mathrm{~b}$ suggest that Brazil is still in an emergent stage. The year of 2015 was the first with over 100 papers. England reached this milestone in 2008 and Spain and USA in 2010. Only Brazil and Mexico achieved this in Latin America. Based on those facts, it is clear that development of studies about education in the Higher Education is still recent, despite the universities presence be a reality in the global education for centuries

Now, considering the language of the papers, Figure 3 shows the language distribution in the world and in Brazil.

Figure 3 - Languages of publications on WoS about education in the Higher Education sector: worldwide and in Brazil.

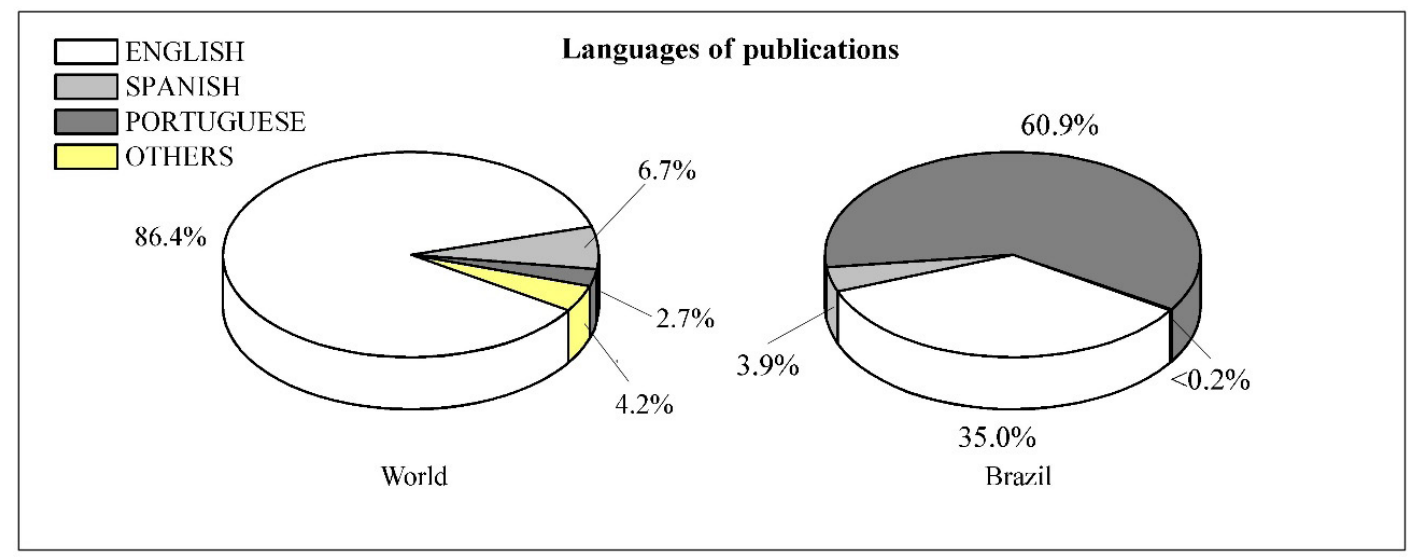

Source: Prepared by the author based on research data.

In total, researchers in this area worldwide published in 35 different languages. However, the results in Figure 3 indicate that English was the major one (86.4\%), followed by Spanish (6.7\%) and Portuguese (2.7\%). By their turn, Brazilian researchers published in 5 different languages: Portuguese, English, Spanish, French and Russian. Only 35.0\% of Brazilian articles were in English. English-speaking countries, as England and USA, showed a higher index (99.6 and 99.0\%, respectively). But countries that speak other languages have a lower English publication index, like Spain with $71.1 \%$ of papers in English. The Brazilian index is low even comparing it inside Latin America. Mexico, Chile and Colombia were among the most cited ones in Figure $1 \mathrm{~d}$ and published 60.2,
51.2 and $55.0 \%$ in English, respectively.

The globalization inspired the internationalization of many institutions of Higher Education all over the world (Jöns \& Hoyler, 2013). In this manner, another possible analysis was the international collaborations. Around $13.4 \%$ of Brazilian articles in this field showed at least one foreigner co-author. England and USA showed 24.4 and $18.2 \%$ of international co-authorship, respectively. In Latin America, Mexico published 21.0\% with at least one other country while Chile published 43.3\% and Colombia published $23.7 \%$. In addition, papers with only Brazilian authors had $66.4 \%$ of the citations of Brazil, with $9.2 \%$ of self-citation index. This index decreased to $8.0 \%$ considering the papers with international collaboration. 
In Figure 4a there is a ranking of countries with more publications with Brazil. The type of collaboration (bilateral or multilateral) about Portugal, Spain and USA is in Figure 4b. These three countries are in Figure $4 \mathrm{~b}$ because they showed the largest interaction with Brazilians (Figure 4a). Overall, Brazilian researchers interacted and published with authors from 40 nations.

Figure 4 - Countries with international collaboration with Brazil in publications on WoS about education in the Higher Education sector.

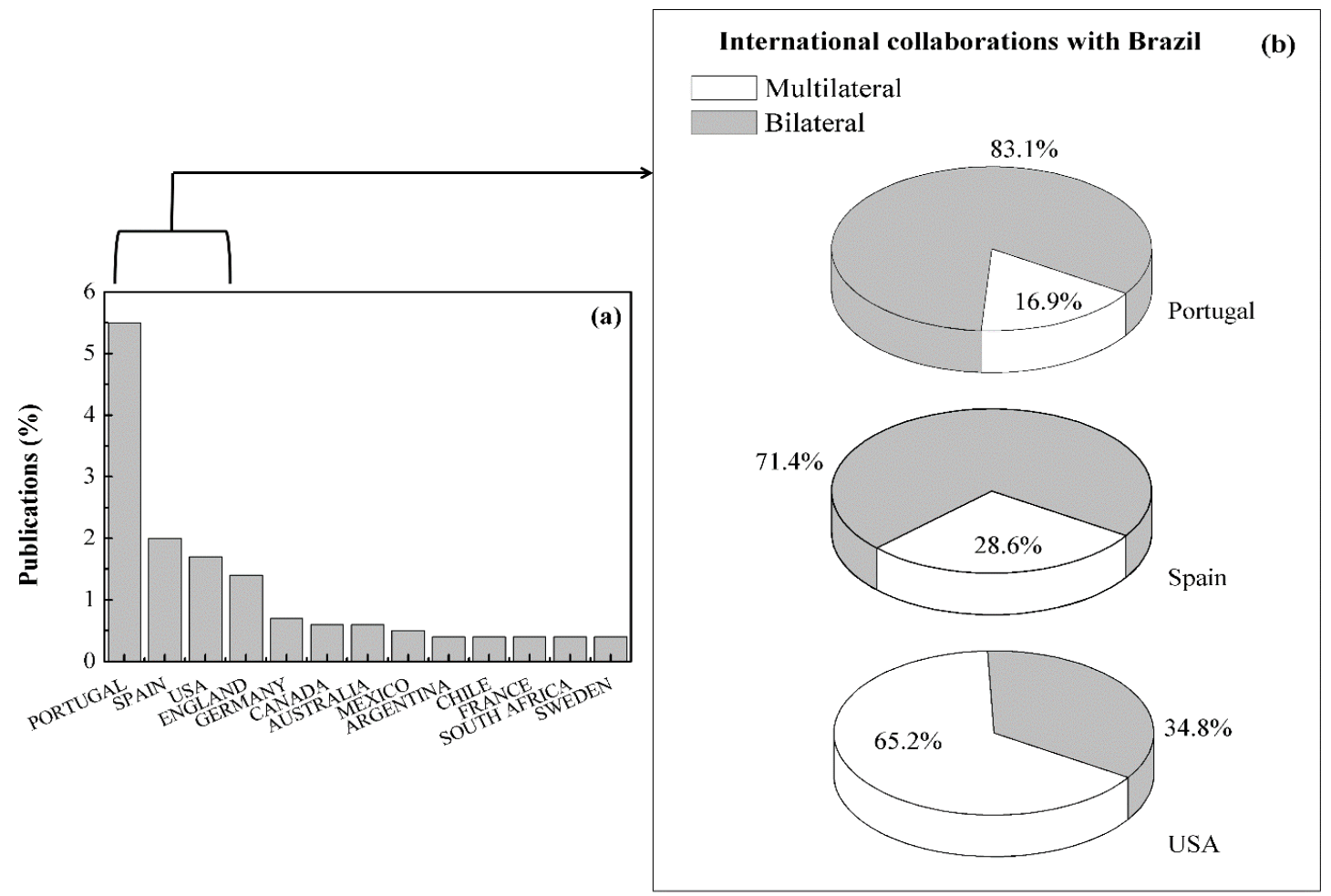

(a) countries with more collaboration; (b) collaborations (multilateral or bilateral) between Brazil and Portugal/ Spain/USA.

Source: Prepared by the author based on research data.

Figure 4a indicates Brazilian researchers looked for more interactions with North America (USA and Canada) and Europe (Portugal, Spain, England, Germany, France and Sweden) rather than other continents. Furthermore, among the 40 countries with publications with Brazil, 25 were European. It is also worth to mention that Coordenação de Aperfeiçoamento de Pessoal de Nível Superior (Higher Education Improvement Coordination - CAPES) is a Brazilian public funding agency. CAPES supported specific international projects with several of the nations in Figure 4a, except, for example, for Australia and South Africa (CAPES, 2019).

Evaluating the collaboration as in Figure 4 is also important because it brings other social impacts as well. For example, Larivière (2011) demonstrated that international projects can involve not only the professors but also their PhD students. So there can be a better capacitation of the researchers of tomorrow (Larivière, 2011).

Portugal, Spain and USA showed the major presence in Figure $4 a$ and their collaborations are in Figure $4 b$. These three countries were also among those with the highest number of Brazilian graduate fellowships outside Brazil (Mazza, 2009; GeoCAPES, 2021). It is possible that USA presence happened not only due to their economic impact worldwide, but also because their influence on the Brazilian graduate system since 1968 (Verhine, 2008). The position of Portugal can be related also with the several government projects involving Brazil and Portugal, such as the Forum on the Governance of Higher Education in the Portuguese Language Countries and Regions or the 
Association of Portuguese Speaking Universities (Bizerril et al., 2018). Besides, this research found that Spain was the major partner in this area to several Latin countries, as Mexico (18.5\% of Mexican papers), Chile (11.7\% of Chilean papers) and Colombia (13.9\% of Colombian papers).

As mentioned earlier in the Method section, there was a second Boolean expression applied on WoS. Thus, it was possible to identify the production of countries concerning all scientific areas during 1945-2020. Thus, Brazil showed $1,100,992$ papers in WoS and its main collaborations were with: USA (123,728 articles - 11.2\%), France $(40,854-3.7 \%)$, England (40,636 - 3.7\%), Germany (36.812 - 3.3\%), Spain (33.595 - 3.1\%), Italy (29,176 - 2.6\%), Canada (27,123 - 2.5\%), and Portugal $(23,802-2.2 \%)$. It is interesting to verify that there was an increasing in the collaborations between Brazil and Spain from 2.5\% in 2012 (Vanz et al., 2016) to $3.1 \%$ in 2020. Further, these data allowed checking the amount of bilateral collaborations with Brazil. In this manner, among the collaborations between Brazil and Spain, 38.8\% were bilateral. Meanwhile, between Brazil and Portugal, 54.1\% were bilateral. On the other hand, between Brazil and USA, 56.9\% were bilateral. Therefore, comparing these results with Figure $4 \mathrm{~b}$, it is clear the solid interaction in Brazil-Portugal and Brazil-Spain relations. Moreover, there is still an opportunity for a better nearness between Brazil and USA through bilateral projects about education in the university sector.

Still concerning the international collaborations between Brazil and other countries, it is possible to study the co-authorship in this area inside MERCOSUR. Until 2021, MERCOSUR members involve Brazil, Argentina, Paraguay, Uruguay and Venezuela (temporarily suspended). MERCOSUR Education Sector is the sector of MERCOSUR responsible for educational public policies in the region, in order to support and to stimulate cooperation among the State members (MERCOSUR, 2021a). There is even an official work group in MERCOSUR Education Sector named as "Work Group of Studies and Researches about Higher Education in Mercosur" (MERCOSUR, 2021b). However, the only nations from MERCOSUR in Figure 4a is Argentina (5 papers $-0.4 \%$ ). This percentage is lower than the international collaborations between Brazil and Argentina considering all areas of Science (1.6\% of general Brazilian publications). These data show that the Brazilian Ministry of Education can provide a better support to MERCOSUR Education Sector in the sector of Higher Education. A future bibliometric research could analyze scientific publications about Brazilian Higher Education looking also at the Brazilian Curriculum Lattes Database. The aim could be to verify the presence of foreigner researches from MERCOSUR working in this area in Brazilian institutions.

Another topic of interesting with these researches would be the keywords chosen by the authors. Figure 5 shows a word cloud of keywords present in Brazilian papers about Higher Education. In total, 2,808 distinct terms were in the suggested keywords by the authors. The most frequent was "Higher Education" (437 times - 31.4\%), followed by "education" (in 102 articles - 7.3\%), "teaching" (92 - 6.6\%), "teacher training" (81 times - 5.8\%) and "distance education" (49-3.5\%).

But some highlights can be mentioned among those one with a fewer use. For instance, specific disciplines with more keywords were those related to Social and Humanities Sciences (38 keywords), Hard Sciences (37 keywords), Health Sciences (29 keywords), and engineering (8 keywords). Among the Social and Humanities, the most common were from Business and Management disciplines. On the other hand, the major disciplines among hard sciences were Math, Computer Science, Biology and Chemistry. Meanwhile, keywords about Health Sciences were basically related to Nursing or Pharmacy. Indeed, the keywords "nursing" and "nursing education" appeared 45 times (3.2\%) and 32 times $(2.3 \%)$, respectively. They were the $6^{\text {th }}$ and $9^{\text {th }}$ most frequent keywords in this dataset, respectively. Still in this context, some keywords were about distance learning, such as "distance education", "distance learning", "e-learning" and "blended learning" occurred in 52 (3.7\%), 17 (1.2\%), 10 (0.7\%) and $g(0.6 \%)$ papers, respectively. 
Figure 5 - Word cloud of the used keywords in Brazilian publications on WoS about education in the Higher Education sector.

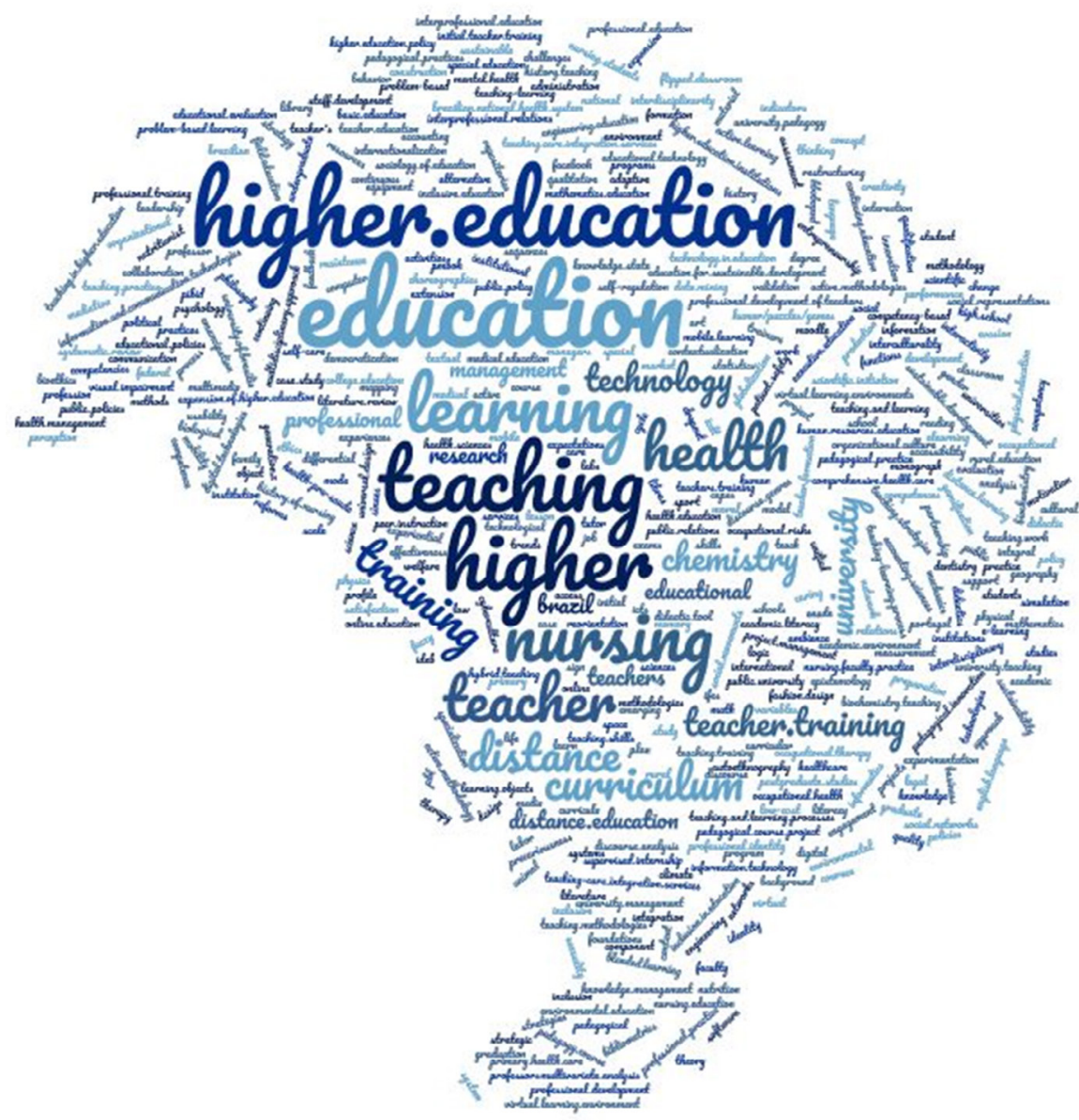

Source: Prepared by the author based on research data.

Brazilian researchers published in 438 different journals, and 134 of them were Brazilian ones. Among all journals, 27 of them published at least 10 papers, 25 of them were Brazilian ones. These 25 Brazilian journals were searched on Twitter and on Facebook, checking if they had an active profile, Table 1 . This is important because an alternative way to measure the impact of publications is to consider indicators from such social media. The science that studies these methods is known nowadays as altmetrics, which is distinct of traditional scientometrics or bibliometrics (Priem \&d Costello, 2011; Thelwall et al., 2013; Costas et al., 2014; Xia et al., 2016).

TABLE 1 - Journals with at least 10 Brazilian papers on WoS about education in the sector of Higher Education and with profiles/pages in Twitter and/or Facebook.

\begin{tabular}{lccc}
\hline Journal & Publications & Twitter profile & Facebook page \\
\hline $\begin{array}{l}\text { Revista Ibero-Americana } \\
\text { de estudos em Educação }\end{array}$ & 68 & - & $\begin{array}{c}\text { @revistaiberoamericana } \\
\text { deestudosemeducacao }\end{array}$ \\
\hline Humanidades \& Inovação & 56 & - & @humanidadeseinovacao \\
\hline $\begin{array}{c}\text { Interface - Comunicação } \\
\text { Saúde Educação }\end{array}$ & 38 & @interface_rev & @interface \\
\hline $\begin{array}{l}\text { Revista Praxis Educacional } \\
\text { Revista On Line De Política } \\
\text { E Gestão Educacional }\end{array}$ & 35 & @PraxisUesb & - \\
\hline $\begin{array}{l}\text { Revista on line de Política e Gestão } \\
\text { Educacional" }\end{array}$
\end{tabular}




\begin{tabular}{|c|c|c|c|}
\hline Journal & Publications & Twitter profile & Facebook page \\
\hline Química Nova & 28 & - & (aquimicanovasbq \\
\hline Educação por Escrito & 26 & - & @revistaeducacaoporescrito \\
\hline $\begin{array}{c}\text { Revista Brasileira De } \\
\text { Enfermagem }\end{array}$ & 25 & @RevenfE & @revbrasenferm \\
\hline Educação & 23 & @revistaeducacao & @revistaeducacao \\
\hline Educar Em Revista & 23 & - & (@educaremrevista \\
\hline $\begin{array}{c}\text { Administração-Ensino } E \\
\text { Pesquisa }\end{array}$ & 22 & - & @revistaraep \\
\hline Holos & 19 & (a) HolosRevista & "Revista Holos" \\
\hline Ciência \& Saúde Coletiva & 18 & (a) RevistaCSC & @revistacienciaesaudecoletiva \\
\hline Movimento & 15 & $\stackrel{\text { @ }}{\text { MovimentoUFRGS }}$ & @movimentorevista \\
\hline $\begin{array}{l}\text { Revista Da Escola De } \\
\text { Enfermagem Da USP }\end{array}$ & 15 & @RevenfE & - \\
\hline $\begin{array}{c}\text { Nuances - Estudos sobre } \\
\text { Educação }\end{array}$ & 12 & - & @revistanuances \\
\hline $\begin{array}{c}\text { Revista de Pesquisa - } \\
\text { Cuidado é Fundamental } \\
\text { Online }\end{array}$ & 11 & @profunirio & @RPCFO \\
\hline
\end{tabular}

Source: Prepared by the author.

The social networks are useful places for informal education and development of critical thinking (Guilherme \& Picoli, 2017). Thus, investing in publicizing academic literature through these platforms should be considered. But only 15 of the 25 searched journals had profiles in Twitter and/or Facebook, Table 1. All these 15 journals were Brazilian. Only 8 of them had profiles or pages both in Twitter and on Facebook: Interface - Comunicação Saúde Educação, Educação por Escrito, Revista Brasileira de Enfermagem, Educação, Holos, Ciência \& Saúde Coletiva, Movimento, Revista da Escola de Enfermagem da USP and Revista de Pesquisa-Cuidado é Fundamental Online.

Moreover, 7 of them had only a Facebook page, but Thelwall et al. (2013) already pointed out that Twitter was the most reliable platform to altmetric studies. In this manner, the editors of these 7 journals could consider create a Twitter profile too, not only a Facebook page. At last, the presence of journals about Health Science in Table 1 can be related to the frequency of keywords in Figure 5 too.
A previous study showed that the number of tweets and Facebook posts of scientific publications had direct relation to their academic citations (Thelwall et al., 2013; Costas et al., 2014). So, it can be a good practice that a journal maintains its active profile in a social media and tweets or posts about their articles. Doing that also can suggest that their editors are concerned about the relevance of their published papers in a broader group of readers, not only the scientists and students of its specific field. There would be a better democratization of knowledge (Xia et al., 2016). In 2019, Brazil had over 8.6 million students and almost 400 thousand professors (Inep, 2020). The university is part of their daily life for years. Therefore, the academic findings about Higher Education are a matter of high interest of all these people. Funding agencies of the Brazilian journals could start to consider these topics in their evaluations too. More altmetric studies are necessary about it, checking the citations of the papers about Higher Education in each social media. 


\section{Brazilian institutions and funding agencies}

This search revealed that 104 Brazilian institutions published at least 4 times in this field. Their distribution between private and public institu- tions is in Figure 6a. In the meantime, 72 funding agencies supported the Brazilian projects and their publications in this area. Figure $6 \mathrm{~b}$ points out how many of them were national or foreigners.

Figure 6 - (a) Type of Brazilian institutions (public/private) and (b) origin from funding agencies concerning publications about education in the Higher Education sector in WoS.

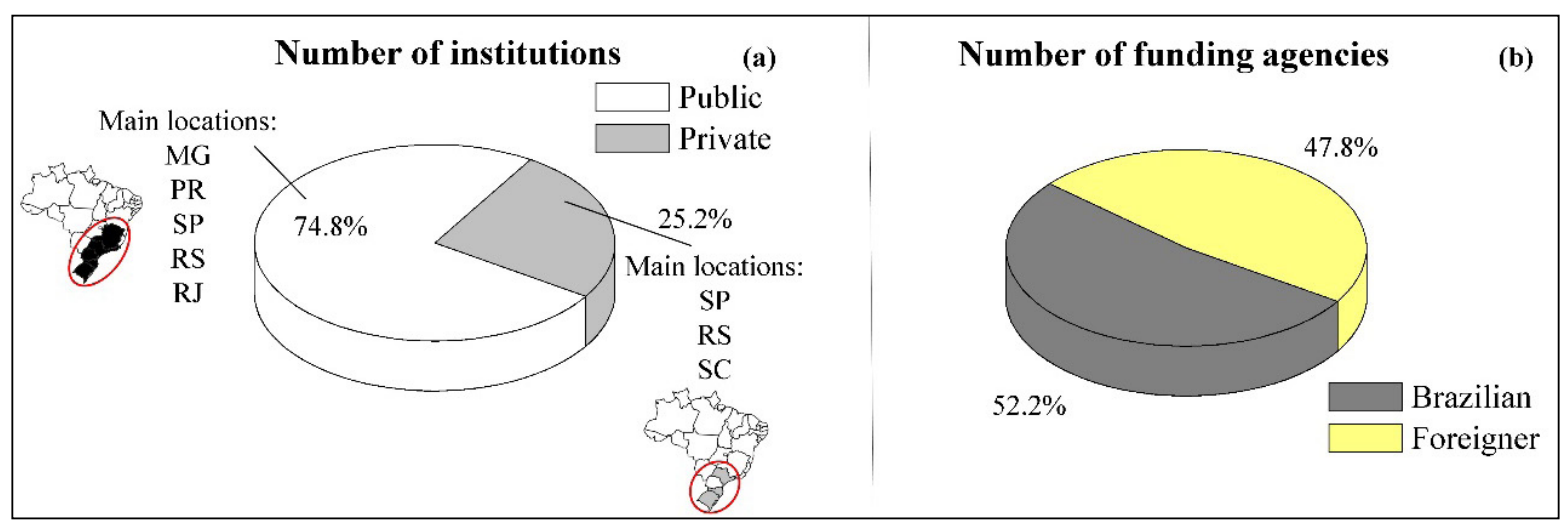

MG: Minas Gerais; PR: Paraná; SP: São Paulo; RS: Rio Grande do Sul; RJ: Rio de Janeiro.

Source: Prepared by the author based on research data.

As shown in Figure 6a, 74.0\% (77 institutions) are public and $26.0 \%$ (27 institutions) are private. This contrast between public and private becomes higher if we check the last Brazilian Higher Education Census which stated that $88.4 \%$ of the Brazilian institutions of Higher Education were private ones (Inep, 2020). Still about Figure 6a, the States with more public institutions were Minas Gerais (MG), Paraná (PR), São Paulo (SP), Rio Grande do Sul (RS), and Rio de Janeiro (RJ). On the other hand, the private ones were most concentrated in São Paulo, Rio Grande do Sul and Santa Catarina. The institutions from the Brazilian South Region (PR, SC and RS) showed a strong presence in public sector and in private one as well.

Considering the funding agencies (Figure 6b), 36 (52.2\%) were nationals and 33 (47.8\%) were foreigners. Among the 36 Brazilian, only 6 were private: the Mackenzie Presbyterian University, Globo Group, the Pontifical Catholic University (PUC) of Rio de Janeiro, Santander Universities Brazil, Paranaense
University (Unipar) and Cesumar Institute of Science, Technology and Innovation (ICETI). Besides that, 30 Brazilian agencies were public, with 2 related to the Federal Government (Ministry of Health and Ministry of Science, Technology, Innovation and Communication), 1 bank (Bank of the Northeast) and 13 universities. These universities were Federal (Federal University of Bahia, Federal University of Ceará, Federal University of Minas Gerais, Federal University of Mato Grosso, Federal University of Santa Catarina, Federal University of Sergipe, University of Brasilia, Federal Institute of Rio Grande do Sul) or State ones (University of São Paulo, State University of São Paulo, State University of Amazonas, State University of Pará and State University of Rio de Janeiro). The participation of the Ministry of Health occurred due to the national program for the formation of professors in health areas (Santos and Batista, 2018). The main institutions and main funding agencies are presented in Figure $7 \mathrm{a}$ and $7 \mathrm{~b}$, respectively. 
Figure 7 - (a) Institutions and (b) funding agencies with more Brazilian papers about education in the Higher Education sector in WoS

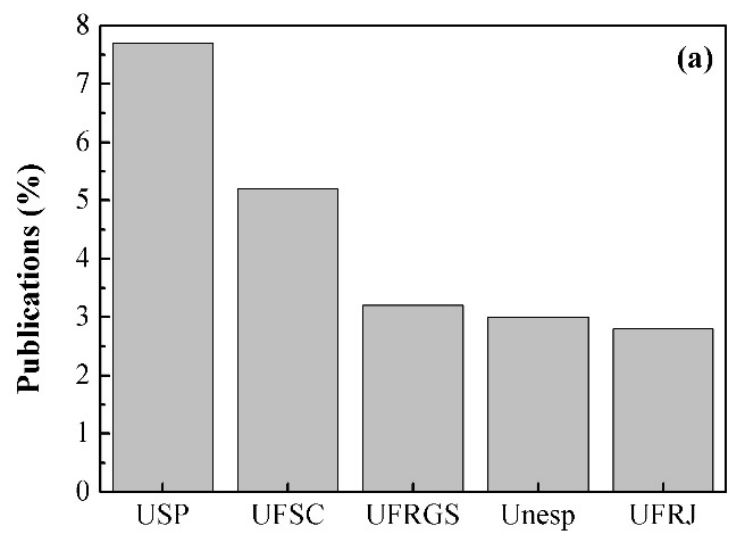

\begin{tabular}{|c|c|}
\hline Institution & Type \\
\hline USP - University of São Paulo & Public \\
\hline $\begin{array}{c}\text { UFSC - Federal University of } \\
\text { Santa Catarina }\end{array}$ & Public \\
\hline $\begin{array}{c}\text { UFRGS - Federal University of } \\
\text { Rio Grande do Sul }\end{array}$ & Public \\
\hline $\begin{array}{c}\text { Unesp }- \text { State University of São } \\
\text { Paulo }\end{array}$ & Public \\
\hline $\begin{array}{c}\text { UFRJ }- \text { Federal University of Rio } \\
\text { de Janeiro }\end{array}$ & Public \\
\hline
\end{tabular}

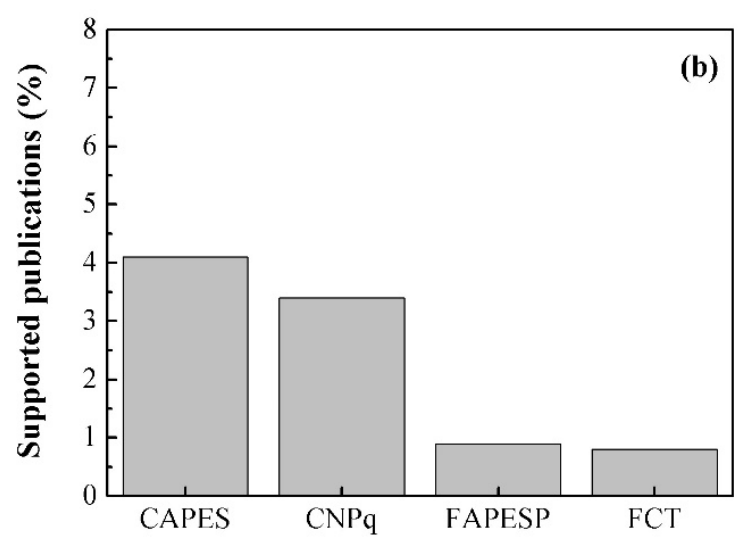

\begin{tabular}{|c|c|}
\hline Funding agency & Country \\
\hline $\begin{array}{c}\text { CAPES - Higher Education } \\
\text { Improvement Coordination }\end{array}$ & Brazil \\
\hline $\begin{array}{c}\text { CNPq - National Council for } \\
\text { Scientific and Technological } \\
\text { Development }\end{array}$ & Brazil \\
\hline $\begin{array}{c}\text { FAPESP }- \text { São Paulo State } \\
\text { Research Foundation }\end{array}$ & Brazil \\
\hline FCT - Foundation for Science and & Portugal \\
\hline Technology & \\
\hline
\end{tabular}

Source: Prepared by the author based on research data.

In the Figure 7a, all institutions are public. Once more, the role of the public sector in this field is highlighted, as in Figure 6a. USP and Unesp are in São Paulo State while UFSC is in Santa Catarina State, UFRGS is in Rio Grande do Sul State and UFRJ is in Rio de Janeiro State. Their concentration in Southeast (SP and RJ) and in South Region (SC and RS) can be related to the number of graduate students in Brazil. They showed the highest numbers in Brazil (GeoCAPES, 2021). A future study could carry out a mapping about collaborations in this field inside Brazil aiming to check if the concentration Southeast-South persists too.

Brazilian private universities did not perform the same impact that of those in Figure 7a. The main private ones were the Pontifical Catholic University (PUC) of Paraná (with 22 papers $-1.6 \%$ of national participation), the PUC of Rio Grande do Sul (19 papers $-1.4 \%$, the University of Vale do Rio dos
Sinos (17 papers $-1.2 \%$ ), the Getulio Vargas Foundation and the PUC of São Paulo (both with 16 papers each $-1.1 \%$ ). All of them are in Southeast or in South Region too, corroborating results in Figure 6a. Moreover, these results partially agree with the generalization stated by Faria et al. (2018) of a Brazilian university ranking. They suggested that the most important Brazilian universities in a research area would be the Federal ones, the Pontifical ones or the State ones (especially USP and the State University of Campinas - Unicamp, both from São Paulo State).

Notwithstanding, it is worth to mention that the quantity of papers shows no direct relation to quality (Adams, 2009). It is necessary to analyze the content of the Brazilian publications, or at least of its highly cited papers, in this field in order to suggest a quality indicator that can be more precise. 
Besides that, Figure $7 \mathrm{~b}$ shows the main funding agencies that had supported researches about university education in Brazil. CAPES and CNPq are agencies related to the Federal Government. Both were among the most important funders of all Brazilian graduate programs (Faria et al., 2018). Meanwhile, FAPESP is a State agency from São Paulo State. FAPESP presence is justified by the national relevance of SP institutions (Figures $5 \mathrm{a}$ and 6a). The prominence of public investments is not an exclusivity of Brazil. Public funds are the core source for university research considering general science worldwide, not only the field of education (Auranen \& Nieminen, 2010). It would be interesting that a future bibliometric research analyzed the funding focused on the publications from Brazilian private universities and their content, comparing these data with those from public institutions. In this manner, it will be possible to verify if there is a state intervention in the private sector of education, as suggested by Alves (2009). At last, the position of FCT-Portugal happened possibly by the strong collaboration between Brazil and Portugal (Figure 4).

In addition, this search revealed several distinct names for the same agencies in the WoS system. For instance, CAPES had 16 variations. Some authors mentioned it only by its initials, others as "Coordination for the Improvement of Higher Education", "Higher Education Personnel Improvement Coordination" or "CAPES Brazilian National Agency", etc. It is important that Brazilian authors pay attention on that and use the standard names suggested by the own agencies. This makes the future identification and acknowledgment easier.

\section{Conclusion}

In this study, I carried out a bibliometric analysis of the Brazilian scientific production about education in the sector of Higher Education. Brazil was among the most prolific publishers worldwide in this field in WoS. It occupied the $7^{\text {th }}$ world position and the $1^{\text {st }}$ in Latin America. However, it is the $24^{\text {th }}$ position in the world citation ranking.

The results also pointed out that Brazilian researchers had used to publish in Portuguese ( 61\%) while the world trend has been in English. It is inte- resting that professors and researchers in this area consider writing in English even in Brazilian journals. This could achieve a better democratization of this knowledge globally, not only inside Brazil or among Portuguese-speaking countries.

Furthermore, the main international collaborations happened with Portugal, Spain and USA. Other studies may arise from this. For example, it is possible to evaluate the location of Brazilian authors which have foreigner collaborators. Is there a Southeast-South concentration as in other contexts? Another topic would be to analyze how and where the national collaborations occur in this field. All these can provide an indicator to encourage improvements in the education quality. This is interesting for the Brazilian Ministry of Education and for funding agencies (State and Federal ones).

Finally, the public universities seemed to dominate the Brazilian scenario, especially USP, UFSC, UFRGS, Unesp and UFRJ. Similarly, the funding of researches about university education came from public agencies, as CNPq, CAPES and FAPESP.

Another suggestion of future study is to verify the content of these papers in this field. Thus, it will be known if they are about a specific course (such as hard sciences or health sciences) or about a broad professor formation in any area. Moreover, the methodology presented here can open other investigations all over the world to strengthen this research subject in any country (e.g. Spain, USA and England), including a comparison between data from Web of Science and SCOPUS.

\section{References}

Adams, J. (2009). The use of bibliometrics to measure research quality in UK higher education institutions. Archivum immunologiae et therapiae experimentalis, 57(1), 19-32. https://doi.org/10.1007/s00005-009-0003-3

Alves, M. (2009). A histórica contribuição do ensino privado no Brasil. Educação, 32(1), 71-78. Available at: https:// revistaseletronicas.pucrs.br/index.php/faced/article/ view/5139

Auranen, O.; Nieminen, M. (2010). University research funding and publication performance: an international comparison. Research Policy, 39(6), 822-834. https://doi. org/10.1016/j.respol.2010.03.003

Biggs, J. (1996). Enhancing teaching through constructive alignment. Higher Education, 32(3), 347-364. https://doi. org/10.1007/BF00138871 
Bizerril, M.; Rosa, M. J.; Carvalho, T.; Pedrosa, J. (2018) Sustainability in higher education: A review of contributions from Portuguese Speaking Countries. Journal of Cleaner Production, 171(1), 600-612. https://doi.org/10.1016/j. iclepro.2017.10.048

Coordenação de Aperfeiçoamento de Pessoal de Nivel Superior. (2019). Cooperação internacional. Ministério da Educação. Available at: wwww.capes.gov.br/cooperaçãointernacional

Costas, R.; Zahedi, Z.; Wouters, P. (2014). Do "altmetrics" correlate with citations? Extensive comparison of altmetric indicators with citations from a multidisciplinary perspective. Journal of the Association for Information Science and Technology, 66(10), 2003-2019. https://doi. org/10.1002/asi.23309

Dias, C. L.; Horiguela, M. L. M.; Marchelli, P. S. (2006). Políticas para avaliação da qualidade do ensino superior no Brasil: um balanço critico. Educação e Pesquisa, 32(3), 435-464. https://doi.org/10.1590/S1517-97022006000300002

Diem, A.; Wolter, S. C. (2013). The use of bibliometrics to measure research performance in education sciences. Research in Higher Education, 54(1), 86-114. https://doi. org/10.1007/s11162-012-9264-5

Durham, E. R. (2018). A qualidade do ensino superior. Revista @mbienteeducação, 2(1), o9-14. Available at: https://publicacoes.unicid.edu.br/index.php/ ambienteeducacao/article/view/475

Faria, J. R.; Wanke, P. F.; Ferreira, J. J.; Mixon, F. G. (2018). Research and innovation in higher education: empirical evidence from research and patenting in Brazil. Scientometrics, 116(1), 487-504. https://doi.org/10.1007/ S11192-018-2744-4

GeoCAPES. (2021). Sistema de Informações Georreferenciadas. Coordenação de Aperfeiçoamento de Pessoal de Nivel Superior. Available at: https://geocapes. capes.gov.br/geocapes

Guilherme, A. A.; Picoli, B. A. (2017). Redes sociais e educação informal: entre o scemo del villaggio e o pensamento crítico. Diálogos Latinoamericanos, 1(26), 23-37. Available at: https://Www.redalyc.org/articulo. oa?id=16254172003

Heradio, R.; De La Torre, L.; Galan, D.; Cabrerizo, F. J.; Herrera-Viedma, E.; Dormido, S. (2016). Virtual and remote labs in education: A bibliometric analysis. Computers \& Education, 98(1), 14-38. https://doi.org/10.1016/j. compedu.2016.03.010

Instituto Nacional de Estudos e Pesquisas Educacionais Anísio Teixeira. (2009). Resumo técnico - Censo da educação superior 2007. INEP. Available at: http:// download.inep.gov.br/download/superior/censo/2007/ Resumo_tecnico_2007.pdf

Instituto Nacional de Estudos e Pesquisas Educacionais Anísio Teixeira. (2020). Sinopse Estatística da Educação Superior 2019. INEP. Available at: http://portal.inep.gov. br/basica-censo-escolar-sinopse-sinopse
Jöns, H.; Hoyler, M. (2013). Global geographies of higher education: The perspective of world university rankings Geoforum, 46(1), 45-59. https://doi.org/10.1016/j. geoforum.2012.12.014

Klein, L.; Schwartzman, S. (1993). Higher education policies in Brazil: 1970-90. Higher Education, 25(1), 21-34. Available at: https://doi.org/10.1007/BF01384039

Larivière, V. (2011). On the shoulders of students? The contribution of PhD students to the advancement of knowledge. Scientometrics, 90(2), 463-481. https://doi. org/10.1007/s11192-011-0495-6

LindblomYlänne, S.; Trigwell, K.; Nevgi, A.; Ashwin, P. (2007) How approaches to teaching are affected by discipline and teaching context. Studies in Higher Education, 31(3), 285-298. https://doi.org/10.1080/03075070600680539

Mazza, D. (2009). Intercâmbios acadêmicos internacionais: bolsas Capes, CNPq e Fapesp. Cadernos de Pesquisa 39(137), 521-547. https://doi.org/10.1590/S010015742009000200010

Maricato, J. M.; Alves, I. M.; Martins, D. L. (2016). Multivariate analysis of major components of factors affecting the (not) researchers accreditation in graduate programs. Revista Ibero-Americana de Ciência da Informação, 9(1), 108-123. https://doi.org/10.26512/rici.vg.n1.2016.2197

Marginson, S. (2016). The worldwide trend to high participation higher education: Dynamics of social stratification in inclusive systems. Higher Education, 72(4), 413-434. https://doi.org/10.1007/s10734-016-0016-x

MERCOSUR. (2021a). Que es el Sector Educativo del Mercosur. MERCOSUL Educativo. Available at: http://edu. mercosur.int/es-ES/institucional/o-que-e.html

MERCOSUR. (2021b). Comissões e grupos de trabalho. MERCOSUL Educativo. Available at: http://sicmercosul. mec.gov.br/es-ES/institucional/comissoes-e-gruposde-trabalho.html

Milanez, D. H.; Amaral, R. M.; Faria, L. I. L.; Gregolin, J. A. R. (2013). Assessing nanocellulose developments using science and technology indicators. Materials Research, 16(3), 635-641. https://doi.org/10.1590/S151614392013005000033

Priem, J.; Costello, K. L. (2010). How and why scholars cite on Twitter. Proceedings of the American Society for Information Science and Technology, 47(1), 1-4. https:// doi.org/10.1002/meet.14504701201

Santos, G. M.: Batista, S. H. S. S. (2018). Docência, Pró-Saúde e PET-Saúde: narrativas de um fazer interprofissional. Interface-Comunicação, Saúde, Educação, 22(1), 15891600. https://doi.org/10.1590/1807-57622017.0728

Smeyers, P.; Burbules, N. C. (2011). How to improve your impact factor: questioning the quantification of academic quality. Journal of Philosophy of Education, 45(1), 1-17. https://doi.org/10.1111/j.1467-9752.2011.00787.x 
Thelwall, M.; Haustein, S.; Larivière, V.; Sugimoto, C. R. (2013). Do altmetrics work? Twitter and ten other social web services. PloS one, 8(5). https://doi.org/10.1371/ journal.pone.0064841

Vanz, S. A. S.; Filippo, D.; Caregnato, S. E.; Garcia-Zorita, C.; Moura, A. M. M.; ...; Sanz-Casado, E. (2016). Scientific collaboration between Brazil and Spain: journals and citations. Encontros Bibli: revista eletrônica de biblioteconomia e ciência da informação, 21(47), 41-50. https://doi.org/10.5007/1518-2924.2016v21n47p41

Vera-Baceta, M. A.; Thelwall, M.; Kousha, K. (2019). Web of Science and Scopus language coverage. Scientometrics, 121(1), 1803-1813. https://doi.org/10.1007/s11192-01903264-z

Verhine, R. E. (2018). Pós-graduação no Brasil e nos Estados Unidos: uma análise comparativa. Educação, 31(2), 166-172. Available at: http://WwW.redalyc.org/articulo. oa?id $=84819177006$

Waltman, L.; CaleroMedina, C.; Kosten, J.; Noyons, E. C. M.; Tijssen, R. J. W.; ...; Wouters, P. (2012). The Leiden Ranking 2011/2012: Data collection, indicators, and interpretation. Journal of the American Society for Information Science and Technology, 63(12), 2419-2432. https://doi.org/10.1002/ asi.22708

Wilson, H. E. (1956). What institutions of higher-education are doing in their teaching and activity programs. Educational Record, 37(2), 107

Winters, J. R. F.; Prado, M. L.; Lazzari, D. D.; Jardim, V. L. T. (2018). Nursing higher education in MERCOSUR: a bibliometric study. Revista Brasileira de Enfermagem, 71(1), 1732-1739. https://doi.org/10.1590/0034-7167-2017-0405

Xia, F.; Su, X.; Wang, W.; Zhang, C.; Ning, Z.; Lee, I. (2016). Bibliographic analysis of nature based on Twitter and Facebook altmetrics data. PloS one, 11(12). https://doi. org/10.1371/journal.pone.0165997

Zhu, J.; Liu, W. (2020). A tale of two databases: the use of Web of Science and Scopus in academic papers. Scientometrics, 123(1), 321-335. https://doi.org/10.1007/ $\underline{\mathrm{s} 11192-020-03387-8}$

\section{Asaph Armando Jacinto}

Professor na FATEC (ZL, Mauá e Tatuapé). Engenheiro de Materiais (UFABC, 2016), recebendo os prêmios do CREA e da Associação Brasileira de Metalurgia, Materiais e Mineração. Também possui graduação em Tecnologia em Polímeros (Faculdade SENAI, 2012), recebendo o Prêmio Lavoisier do Conselho Regional de Química - IV Região, e em Bacharelado em Ciência e Tecnologia pela UFABC. Especialista em Gestão e Docência no Ensino Superior (Unoeste, 2019). É mestre (2016) e doutor (2020) em Nanociências e Materiais Avançados (UFABC).

\section{Correspondence address}

Av. Antônio Rosa Fioravanti, 804

Centro - 09390-120

Mauá, SP, Brazil

Os textos deste artigo foram revisados por Zeppelini Publishers e submetidos para validação do(s) autor(es) antes da publicação. 